\title{
FOREIGN CAPITAL AND CREDIT MARKET DEVELOPMENT: THE CASE OF LITHUANIA
}

\author{
Aleksandras Vytautas Rutkauskas', Gitana Dudzevičiūtè2 \\ Vilnius Gediminas Technical University, Sauletekio al. 11, LT-10223 Vilnius-40, Lithuania \\ 1E-mail:ar@vv.vtu.lt \\ ${ }^{2}$ E-mail: gitana_dudz@yahoo.com \\ Received 0508 2005; accepted 14092005
}

\begin{abstract}
There have been wide-ranging discussions on whether the investments of foreign banks into the banking sector of the Central and Eastern Europe countries (CEE) lead to greater competition and increase of the loan portfolio of the banks. Several empirical works have shown that a high proportion of foreign capital in the banking sector of CEE countries has generally positive effects on the quality and amount of loan portfolio of the banking sector, but there may also be some adverse effects.

Lithuania has an open economy and the credit market is open to international banking competition. The loan portfolio of the banks in Lithuania was growing very rapidly during the last year. A drop in the loan interest rates was significant and banks offered credits under favourable conditions. At the same time, the Lithuanian banking sector is largely foreignowned. Foreign investors currently own approx. $87 \%$ of the share capital of banks in Lithuania.
\end{abstract}

The aim of this paper is to investigate the link between the Lithuanian credit market development and the entry of foreign banks.

Keywords: financial liberalisation, foreign capital, loan portfolio, interest rate, credit market, money and capital market, gross domestic product (GDP).

\section{Introduction}

The liberalisation of financial markets in Central and Eastern Europe countries (CEE) allows foreign banks to enter these countries. The financial markets integration accelerates concentration, raises efficiency and strengthens competition. Foreign banks generally have better access to the international money and capital markets and are therefore better able to supply credits, even though local savings are low. Foreign banks use the potential ability better. They may offer services abroad at lower costs. The local banks have possibilities to take over the experience from the parent bank [1]. Foreign investors bring capital and foster the implementation of best practices in the domestic banking system. The banks go abroad to better serve their domestic clients, who have gone abroad also to do business with local individuals by offering them high -quality services.

While the share of foreign capital has risen from 16\% to $87 \%$ in Lithuania within ten years, the ratio of bank loans to GDP has increased from $15 \%$ to $28 \%$. Therefore, it would be worth analyzing the impact of foreign capital on the loan portfolio amount of the Lithuanian banking sector.

\section{Internationalisation and banking sector development: review of studies}

There are a lot of theories trying to explain why firms at a certain stage of development start investing abroad, how they do this and what the development implications of such activities are.

The most general theoretical framework is Dunning's model $[2,3]$. It explains why firms decide to start investing abroad, where they invest and why they select foreign direct investment (FDI) out of the many forms of foreign market entry. The important aspect of this theory is that the location and ownership advantages are necessary but not in themselves a sufficient condition for FDI. They should be complemented by internationalisation, which helps to take the advantages of such conditions.

The main aspect of Resource-based theory is firms' capabilities [4]. The basic idea of this theory is that 
the accumulation of a firm's specific advantages is a cumulative process and that it is important to differentiate between the visible and invisible components of technology.

The Nordic internationalisation model [4] looked only at which firms start to invest abroad and in which forms they enter foreign markets. The basic idea is that internationalisation is in stages and that firms start internationalising through simple activities and only later, after becoming more experienced, they undertake more sophisticated forms of activities.

There are some explanations trying to establish a pattern of expansion of the banking internationalisation. One of the most common explanations is related to the increase of banking competition. As margins and fees are tightened in domestic markets, banks seek to generate higher returns expanding their activity. They invest in markets with growth potential and greater net interest margins. Earnings diversification lowers the bank risk and reduces the possibility of failure [5].

The theory of international banking was developed by Grubel H. and later the economists discussed and tried to answer some of the questions related to the impact of foreign banks on the domestic banking market [6]. The theory of international banking is linked with the theory of foreign direct investments (FDI). It was stressed that foreign direct investments are a key component of external financing of the domestic economies. Foreign investors bring capital and foster the implementation of best practices in the domestic banking system. Banks go abroad to better serve their domestic clients, who have gone abroad also to do business with local individuals by offering them highquality services. The international banking sector grows together with FDI as banks put their efforts to satisfy the demand for the banking services of international companies abroad.

The economists Rugman and Kamath [7] point out the main aspects of the importance of foreign ownership. Foreign banks reduce banking regulations. In many cases, the main target of establishment subsidiaries abroad is to overcome the restrictions on moving capital abroad. Foreign ownership reduces the risk. As the macroeconomic situation may change, being present will enable banks to determine the risk in time and take the necessary measures. Foreign banks use the potential ability better. They may offer services abroad at lower costs. The local banks have possibilities to take over the experience from the parent bank. Foreign banks use the reputation of a parent bank. They get competitive advantages and they are considered more reliable than local banks.

The benefits of the foreign ownership in the banking system were examined in different aspects. For example, Caprio G. and Honahan P. [5] in their empirical studies have shown a positive correlation between the foreign ownership of banks and the stability of banking sector. They found that the foreign banks contribute to the lending growth and to the greater credit stability than the domestic banks. Foreign banks can provide more stable source of credits and help to avoid the credit risk because they hold more diversified portfolio and have better access to the international financial markets. Foreign ownership stimulates competition, development of financial markets, introduction of new banking technology and financial innovations.

However, foreign capital was not entirely without shortcomings. There are also some approaches that foreign capital may worsen the stability of the banking sector in the host country. For instance, in many foreign-owned banks, the main activities such as trading were shifted to the headquarters. The subsidiaries in some countries lost some important functions. Moreover, the stability of the system would depend on the stability of the home institutions and the local regulators. Referring to the Anderson's and Chantal's [4] arguments, foreign banks may have different objectives. They may be interested only in promoting exports or in supporting special projects.

To sum up different theories, approaches and empirical studies related with the financial internationalisation, it must be said that the entry of foreign banks brings more positive than negative effects to the national banking sector development.

\section{Foreign capital and banks' loan portfolio in Lithuania}

\subsection{High degree of foreign capital in the banking sector of Lithuania}

Dominant foreign ownership in the European Union (EU) new member states' banking sector is a feature that separates the EU new member states from the oldtimers. Foreign investors own more than two-thirds of the banking system in the EU new member states. A high degree of foreign capital, in particular, is in the Lithuanian banking sector, where all major banks are under the foreign investors' control. The share of foreign capital has risen from $16 \%$ to $87 \%$ in the Lithuanian banking sector within ten years (Fig 1).

The significant growth of foreign capital in the 


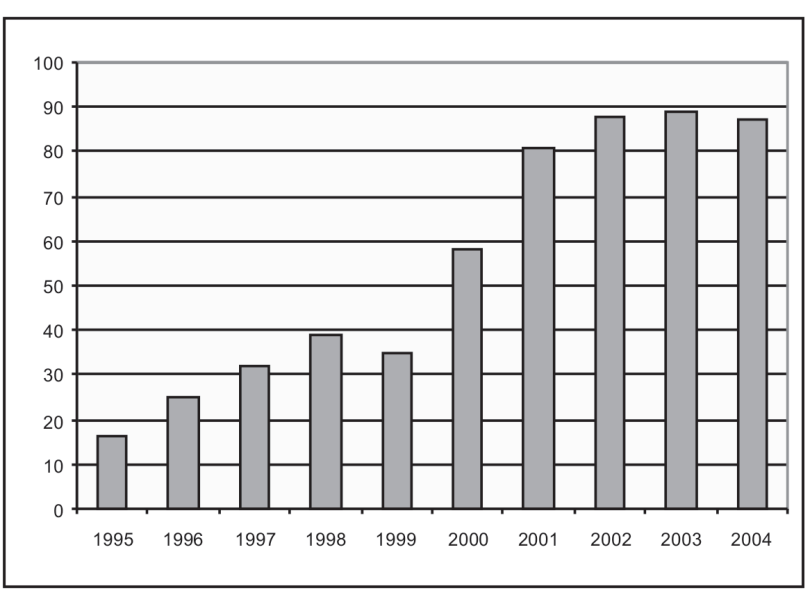

Fig 1. Share in \% of foreign ownership in total banks' share capital in Lithuania

Lithuanian banking sector, in particular, was during the period of 2000-2002. Foreign banks acquired over $90 \%$ of the equity of the main three banks in Lithuania (AB Vilniaus Bankas, AB Lietuvos Žemès ūkio Bankas, AB Taupomasis Bankas) and became their major shareholders. In 2000, Skandinaviska Enskilda Banken (SEB) acquired $98 \%$ of Vilniaus Bankas equity and became its major shareholder. In 2001, AS Hansabank became the major shareholder of AB Taupomasis Bankas with a share stake of $90.7 \%$. In 2002, the privatisation of AB Lietuvos Žemès ūkio Bankas was completed. The German bank NORD/LB acquired $93.1 \%$ of the bank's equity. The new owners changed the names of the Lithuanian banks.

In general, foreign banks entered the Lithuanian banking market in the same way as in other transition countries, when the local banks were in difficulties. For example, during the period of 1999-2000, the share of foreign capital in the Croatian banking sector increased to approx. $90 \%$. By the end of 2002, $86.6 \%$ of the shares in Estonian commercial banks were in the ownership of non-residents.

Foreign owners offer new banking services, foster the implementation of best practices in the domestic banking system as well as enable the banks to expand their activities. The decrease in the capital adequacy ratio of the Lithuanian banking sector shows that before the foreign banks' entry, Lithuanian banks were more conservative and careful (Fig 2). Foreign capital has opened the new possibilities for the expansion of the investment activities, development of the banking services and new business opportunities. Lithuanian banks became more secure.

With the foreign capital entry the capital adequacy of the Lithuanian banking sector decreased from $17.6 \%$ in 1999 to $12.3 \%$ in 2004 [8]. In September 2004, the capital adequacy requirement was reduced from $10 \%$ to $8 \%$.

\subsection{The tendencies of the loan portfolio in the Lithuanian banking sector}

The amount of loan portfolio of the Lithuanian banks has been influenced by the general growth of the economy and banking sector development. Despite the drop in the number of banks, the Lithuanian banking sector has grown rapidly. The growth of the banking assets has been faster than GDP growth. The banking sector assets as a percentage of GDP increased from $25 \%$ in 1995 to $48 \%$ at the end of 2004 .

The Lithuanian credit market can be characterized as a market with a very high degree of concentration. It means that the major part (approx.70\%) of the banking sector loan portfolio is concentrated in the three largest banks of Lithuania. This reason can increase probability of the systematic risk and decrease competition of the banking sector.

The loan portfolio of the banking sector in Lithuania has experienced a fast growth (Fig 3).

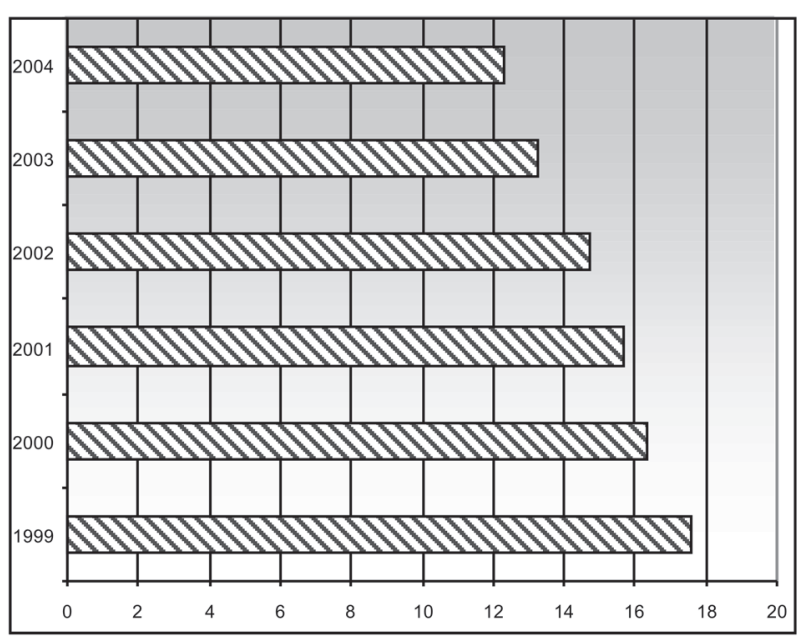

Fig 2. Capital adequacy level of the Lithuanian banking sector, $\%$

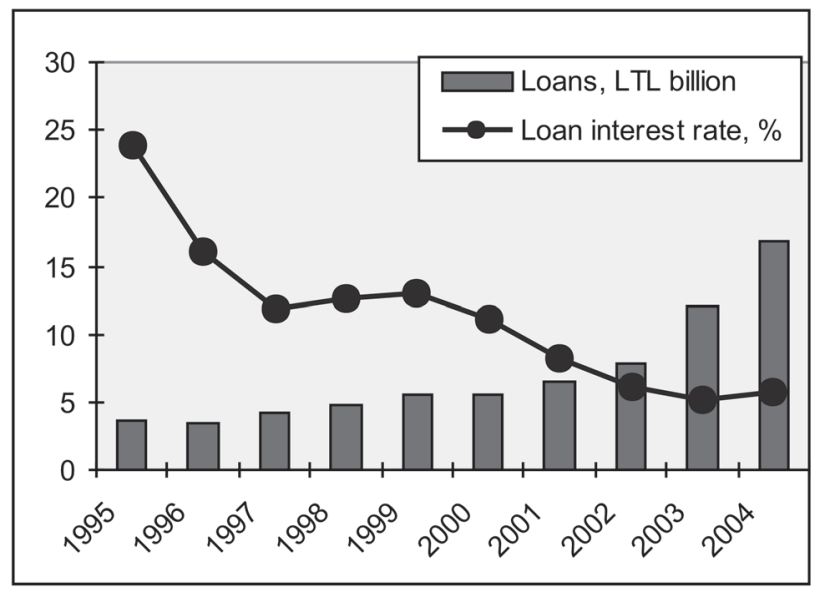

Fig 3. Loan portfolio tendencies in the Lithuanian banks 
The tendencies of the loan portfolio in the Lithuanian banks during the period of ten years can be explained dividing this period into two stages. From 1995 to 1999, the growth of the loan portfolio in the Lithuanian banking sector was quite moderate. It was determined by the general situation of the economy: modest economic growth, relative high level of unemployment and financial crisis in Russia. From 2000 the loan portfolio in the Lithuanian banking sector has been growing steadily. The particularly significant growth was in 2003 and 2004.

In 2000-2002, foreign banks acquired over $90 \%$ of the equity of the main three banks in Lithuania $(\mathrm{AB}$ Vilniaus Bankas, AB Lietuvos Žemès ūkio Bankas, $\mathrm{AB}$ Taupomasis Bankas) and became their major shareholders. After the entry of foreign banks into the market, the banks started to assess credit risk much more carefully and limited the loan portfolio growth to some degree until the beginning of 2003, when the banking sector was stabilised.

The demand for loans in Lithuania is currently very high due to falling interest rates and good loan conditions. The interest rates on loans decreased from $23.9 \%$ in 1995 to $5.6 \%$ in 2004 because of lower risks [8].

Total loans provided by banks as a share of GDP has also risen significantly. The loan portfolio as a percentage of GDP increased from $15 \%$ in 1995 to $28 \%$ by the end of 2004 (Fig 4).

Foreign capital involvement has made loan conditions for the private sector more favourable, the credit ratings of the banks in Lithuania have risen due to strong foreign owners, and higher credit ratings give a possibility for the banks to lower interest rates. Banking intermediation in Lithuania, however, remains relatively low in comparison with the EU countries. The banks' loan portfolio amounts to about $100 \%$ of GDP in the euro area [9]. The corresponding figure for Lithuania amounts to $28 \%$ of GDP in 2004 (Fig 4).

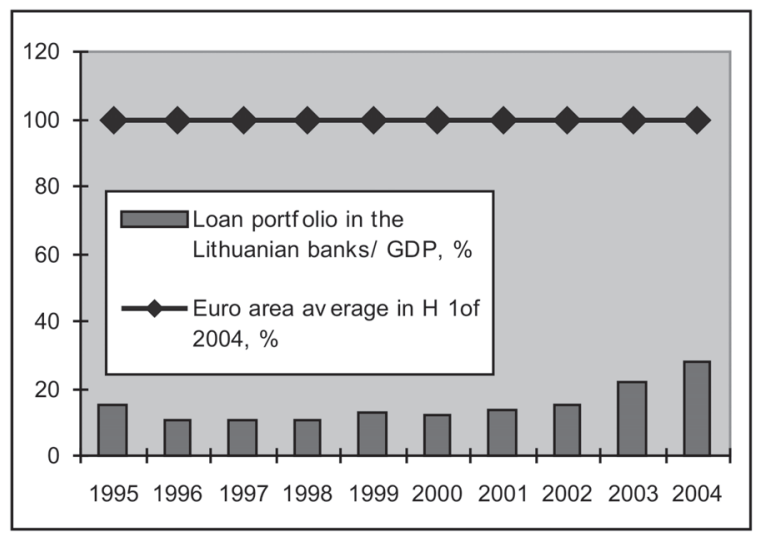

Fig 4. The tendencies of loan portfolio in \% of GDP
There are some reasons for the low levels of the loan portfolio amount in the Lithuanian banking sector. Lithuania experienced a sharp economic downturn upon transition. The output dropped down approx. 35$40 \%$ in Lithuania over the first few years of transition. This led to massive bad- debt problems and significant reduction of the loan portfolio of the banking sector. It took several years to recover from that banking and macroeconomic crisis.

The individual loan portfolio as well as the total loan portfolio in the Lithuanian banking sector kept growing rapidly in the third quarter of 2003 (Fig 5).

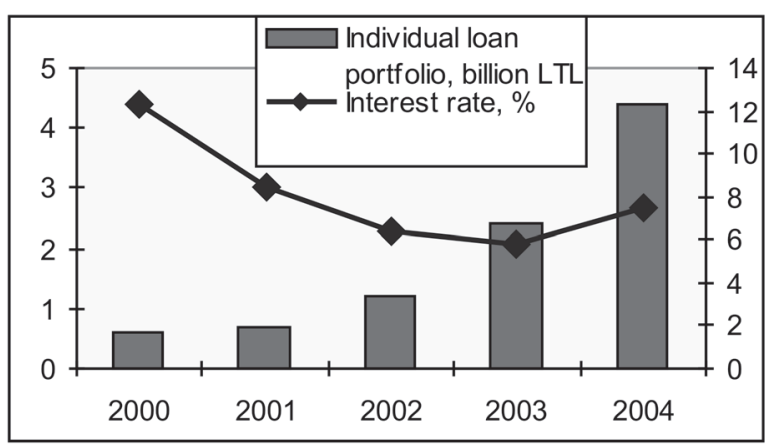

Fig 5. Individual loan portfolio in the Lithuanian banking sector

Loans granted to customers increased by LTL 2 billion or $83 \%$ in 2004. Loans granted to individuals, with mortgage loans prevailing among them, continued to be an item of banking assets characterised by a most dynamic growth. Mortgage loans increased by LTL 1,5 billion or $80 \%$ in 2004. In spite of a significant growth of mortgage loans in the Lithuanian banking sector, mortgage loans as a percentage of GDP in Lithuania make approx. $5.6 \%$ in comparison with $35 \%$ in the Euro area $[9,10]$. There is enough potential for the growth of mortgage loans in Lithuania.

\section{Relationship between the credit market development and the entry of foreign banks}

To study the impact of foreign banks entry on the Lithuanian credit market, we used the correlation and regression analysis. Balance sheet data were analysed and ratios of the banking sector for the period 1997 2004 were calculated. The variables for the analysis are determined and given in Table 1.

Dependent variable Y, loan portfolio/ GDP is determined by X1 - deposits / GDP, X2 - problem loans / total loans, X3 - foreign capital / total share capital and X4 - liabilities to foreign banks / assets (Table 2). 
Table 1. The variables for the regression analysis

\begin{tabular}{|c|c|c|c|c|}
\hline $\begin{array}{c}\text { Loan } \\
\text { portfolio / } \\
\text { GDP }\end{array}$ & $\begin{array}{c}\text { Deposits / } \\
\text { GDP }\end{array}$ & $\begin{array}{c}\text { Problem } \\
\text { loans / } \\
\text { total loan } \\
\text { portfolio }\end{array}$ & $\begin{array}{c}\text { Foreign } \\
\text { capital / } \\
\text { total share } \\
\text { capital }\end{array}$ & $\begin{array}{c}\text { Liabilities } \\
\text { to foreign } \\
\text { banks / } \\
\text { assets }\end{array}$ \\
\hline $\mathbf{Y}$ & $\mathbf{X 1}$ & $\mathbf{X 2}$ & $\mathbf{X 3}$ & $\mathbf{X} 4$ \\
\hline
\end{tabular}

Table 2. Initial data for the analysis, $\%$

\begin{tabular}{|c|c|c|c|c|c|}
\hline Year & $\begin{array}{c}\text { Loan } \\
\text { portfolio } \\
\text { / GDP }\end{array}$ & $\begin{array}{c}\text { Deposits } \\
\text { / GDP }\end{array}$ & $\begin{array}{c}\text { Problem } \\
\text { loans / } \\
\text { total } \\
\text { loan } \\
\text { portfolio }\end{array}$ & $\begin{array}{c}\text { Foreign } \\
\text { capital / } \\
\text { total } \\
\text { share } \\
\text { capital }\end{array}$ & $\begin{array}{c}\text { Liabiliti- } \\
\text { es to } \\
\text { foreign } \\
\text { banks / } \\
\text { assets }\end{array}$ \\
\hline 1997 & 10.5 & 15,2 & 28.3 & 32 & 7.3 \\
\hline 1998 & 10.7 & 14,2 & 12.5 & 39 & 14.6 \\
\hline 1999 & 12.8 & 16,0 & 11.9 & 35 & 16.2 \\
\hline 2000 & 12.1 & 18,9 & 10.8 & 58 & 10.6 \\
\hline 2001 & 13.5 & 21,5 & 7.5 & 81 & 13.7 \\
\hline 2002 & 15.4 & 22,7 & 5.8 & 88 & 14.8 \\
\hline 2003 & 21.7 & 24,4 & 2.6 & 89 & 22.6 \\
\hline 2004 & 27.9 & 29,5 & 2.0 & 87 & 22.7 \\
\hline
\end{tabular}

At first, we calculate correlation coefficients between $\mathrm{Y}$ and every $\mathrm{X}$.

The correlation coefficients are significant, when $\mathrm{t}^{\mathrm{sk}}$ $>t^{\text {lent }}$. X2 turned out to be statistically insignificant and was removed from the further analysis (Table 3).

Table 3. Correlation coefficients and their significance

\begin{tabular}{|c|c|c|c|}
\hline $\mathbf{r}$ YX1 & $\mathbf{Y X 2}$ & $\mathbf{r} \mathbf{Y X 3}$ & $\mathbf{r} \mathbf{Y X 4}$ \\
\hline 0,9238 & $-0,6982$ & 0,7127 & 0,8641 \\
\hline $\mathbf{t}^{\text {sk }} \mathbf{Y X 1}$ & $\mathbf{t}^{\text {sk }} \mathbf{Y X 2}$ & $\mathbf{t}^{\text {sk }} \mathbf{Y X 3}$ & $\mathbf{t}^{\text {sk }} \mathbf{Y X 4}$ \\
\hline 5,9091 & $-2,3889$ & 2,4888 & 4,2046 \\
\hline $\mathrm{t}^{\text {lent }}$ & $\mathrm{t}^{\text {lent }}$ & $\mathrm{t}^{\text {lent }}$ & $\mathrm{t}^{\text {lent }}$ \\
\hline 2,4469 & 2,4469 & 2,4469 & 2,4469 \\
\hline
\end{tabular}

The next step of the investigation is the testing of multicollinearity among X1, X3, X4. In order to evaluate multicollinearity, we made the matrix of correlation indicators.

Table 4 shows the significant correlation coefficient between $X 1$ and $X 3$. Taking into account that correlation YX1 is stronger than $\mathrm{YX} 3$, the variable $\mathrm{X} 3$ is excluded from the analysis.

This decision was tested using Helving's method, which showed what combination of the variables has to be used for making the regression equation (Table 5).

Combination of variables $\mathrm{X} 1 \mathrm{X} 4$ is the best for the
Table 4. The matrix of correlation indicators

\begin{tabular}{|c|c|c|c|c|}
\hline & $\mathrm{Y}$ & $\mathrm{X} 1$ & $\mathrm{X} 3$ & $\mathrm{X} 4$ \\
\hline $\mathrm{Y}$ & 1 & & & \\
\hline $\mathrm{X} 1$ & 0,9238 & 1 & & \\
\hline $\mathrm{X} 3$ & 0,7127 & 0,8982 & 1 & \\
\hline $\mathrm{X} 4$ & 0,8641 & 0,7309 & 0,6206 & 1 \\
\hline
\end{tabular}

Table 5. The application of Helving's method

\begin{tabular}{|l|l|l|l|l|}
\hline 1$) \mathrm{x} 1$ & & & & \\
\hline & $\mathrm{h}=$ & 0,8534 & $\mathrm{H} 1=$ & 0,8534 \\
\hline & & & & \\
\hline 3$) \mathrm{x} 4$ & $\mathrm{~h}=$ & 0,5080 & $\mathrm{H} 2=$ & 0,5080 \\
\hline & $\mathrm{h}=$ & 0,7466 & $\mathrm{H} 3=$ & 0,7466 \\
\hline 4) $\mathrm{x} 1 \mathrm{x} 3$ & & & & \\
\hline & $\mathrm{h} 1=$ & 0,4496 & $\mathrm{H} 4=$ & 0,7172 \\
\hline & $\mathrm{h} 3=$ & 0,2676 & & \\
\hline 5$) \mathrm{x} 1 \mathrm{x} 4$ & & & & \\
\hline & $\mathrm{h} 1=$ & 0,4930 & $\mathrm{H} 5=$ & 0,9244 \\
\hline & $\mathrm{h} 4=$ & 0,4313 & & \\
\hline 6) $\mathrm{x} 3 \mathrm{x} 4$ & & & & \\
\hline & $\mathrm{h} 3=$ & 0,3134 & $\mathrm{H} 6=$ & 0,7741 \\
\hline & $\mathrm{h} 4=$ & 0,4607 & & \\
\hline & & & & \\
\hline 7) $\mathrm{x} 1 \mathrm{x} 3 \mathrm{x} 4$ & & & & \\
\hline & $\mathrm{h} 1=$ & 0,3246 & $\mathrm{H} 7=$ & 0,8438 \\
\hline & $\mathrm{h} 3=$ & 0,2017 & & \\
\hline & $\mathrm{h} 4=$ & 0,3175 & & \\
\hline & & & & \\
\hline & & & & \\
\hline & & & & \\
\hline & & & & \\
\hline & & & & \\
\hline & & & & \\
\hline & & & & \\
\hline & & & & \\
\hline & & & & \\
\hline & & & & \\
\hline & & & & \\
\hline & & & & \\
\hline
\end{tabular}

$\mathrm{H}$ max. value $=0,9244$

regression analysis due to the highest coefficient $\mathrm{H}$ $(0,9244)$.

Using ToolPak Data Analysis, we calculate regression statistics and make the regression equation.

R Square indicates that approx. $93 \%$ of the variation in credit market development $(\mathrm{Y})$ can be explained by using X1 and X4 (Table 6). The relationship between

Table 6. Regression statistics

\begin{tabular}{|l|l|}
\hline Regression statistics & \\
\hline Multiple R & 0,9643 \\
\hline R Square & 0,9299 \\
\hline Adjusted R Square & 0,9020 \\
\hline Observations & 8 \\
\hline
\end{tabular}


$\mathrm{Y}, \mathrm{X} 1$ and $\mathrm{X} 4$ can be explained by equation:

$$
Y=-6,54+0,74 X I+0,47 X 4 \text {. }
$$

Clients' deposits and liabilities to foreign banks have a positive impact on the credit market development. Clients' deposits are the main financial (credit) resources of the banking sector and make approx. $60 \%$ in total liabilities of the Lithuanian banking sector. The deposits of the banking sector have increased from LTL 3,7 billion to LTL 17,9 billion over ten years. Liabilities to foreign banks increased by 5 times from 1998 to 2004. This fact can be explained by the growing share of the foreign bank's capital in the Lithuanian banking sector. The credit market development was supported by better access to the foreign money markets due to foreign strategic investments in the Lithuanian banking sector. Foreign capital involvement has made loan conditions more favourable and gives a possibility for the banks to lower interest rates.

\section{Conclusions}

1. The aim of this paper is to analyse the link between the credit market development in Lithuania and the entry of foreign banks.

2. The empirical studies have shown that a high proportion of foreign capital in the banking sector of the Central and Eastern Europe countries has generally positive effects on the quality and amount of the loan portfolio of the banking sector.

3. The Lithuanian banking sector is largely foreignowned. Foreign investors currently own approx. $87 \%$ of the share capital of the Lithuanian banks.

4. The significant growth of foreign capital in the Lithuanian banking sector, in particular, was during the period of 2000-2002. Foreign banks acquired over $90 \%$ of the equity of the largest banks in Lithuania (AB Vilniaus Bankas, AB Lietuvos Žemès ūkio Bankas, AB Taupomasis Bankas) and became their major shareholders.

5. Foreign owners offer new banking services, foster the implementation of best practices in the domestic banking system as well as enable the banks to expand their activities.

6. With the foreign capital entry the capital adequacy of Lithuanian banking sector decreased from $17.6 \%$ in 1999 to $12.3 \%$ in 2004 . It shows that before the foreign banks' entry, Lithuanian banks were more conservative and careful.
7. The Lithuanian credit market can be characterized as a market with a very high degree of concentration. It means that the major part (approx.70\%) of the banking sector loan portfolio is concentrated in the three largest banks of Lithuania. This reason can increase a probability of the systematic risk and decrease competition of the baking sector.

8. The demand for loans in Lithuania is currently very high due to falling interest rates and good loan conditions. The interest rates on loans decreased from $23.9 \%$ in 1995 to $5.6 \%$ in 2004 because of lower risks.

9.The loan portfolio as a percentage of GDP increased from $15 \%$ in 1995 to $28 \%$ at the end of 2004 in the Lithuanian banking sector (the corresponding ratio in the Euro area amounts to $100 \%$ ).

10. The regression analysis shows that the credit market development in Lithuania was supported by an increase in clients' deposits and liabilities to foreign banks due to their better access to the foreign money markets.

\section{References}

1. Zsolt, B and Ping, W. The Financial Development and Growth. New York: FRB, 2000.

2. Dunning, J.H. Multinational Enterprises and the Global Economy. Wokinghann: Addison - Wesley Publishers, 1993.

3. Dunning, J.H. International Production and the Multinational Enterprise. London: Allen and Unwin, 1981.

4. Anderson, R.W., Chantal, K. Transition Banking: Financial Development of Central and Eastern Europe. Clarendon Press, Oxford, 1998.

5. Caprio, G. and Honohan, P. Finance for Growth: Policy Choices in a Volatile World. The World Bank, Washington DC., 2000.

6. Grubel, H. A Theory of Multinational Banking, Banka Nazionale del Lavozo, Quarterly Review No. 123, 1997.

7. Rugman, A. M., Kamath, S. J. International Diversification and Multinational Banking in Recent Developments in International Banking and Finance. McGraw-Hill, London, 1987.

8. www.lb.lt

9. www.eurostat.com

10. www.eib.org 